Published in final edited form as:

J Control Release. 2014 September 28; 0: 440-450. doi:10.1016/j.jconrel.2014.05.037.

\title{
Non-viral nanocarriers for siRNA delivery in breast cancer
}

\author{
Jing Zhanga , Xiang Li ${ }^{\mathrm{a}}$, and Leaf Huang ${ }^{\mathrm{b},{ }^{*}}$ \\ aKey Laboratory of Modern Preparation of TCM, Ministry of Education, Jiangxi University of \\ Traditional Chinese Medicine, Nanchang, China \\ bDivision of Molecular Pharmaceutics and Center of Nanotechnology in Drug Delivery, Eshelman \\ School of Pharmacy, University of North Carolina at Chapel Hill, Chapel Hill, NC 27599, USA
}

\begin{abstract}
Breast cancer is the most frequently diagnosed malignancy in American women. While significant progress has been made in development of modern diagnostic tools and surgical treatments, only marginal improvements have been achieved with relapsed metastatic breast cancer. Small interfering RNAs (siRNAs) mediate gene silencing of a target protein by disrupting messenger RNAs in an efficient and sequence-specific manner. One application of this technology is the knockdown of genes responsible for tumorigenesis, including those driving oncogenesis, survival, proliferation and death of cells, angiogenesis, invasion and metastasis, and resistance to treatment. Non-viral nanocarriers have attracted attention based on their potential for targeted delivery of siRNA and efficient gene silencing without toxicity. Here, we review promising, non-viral delivery strategies employing liposomes, nanoparticles and inorganic materials in breast cancer.
\end{abstract}

\section{Keywords}

Breast cancer; Small interfering RNAs (siRNAs); Target genes; Non-viral nanocarriers

\section{Introduction}

\subsection{Challenges in breast cancer treatment}

Breast cancer is the most commonly diagnosed malignancy in American women with an estimated 39510 fatalities per year, accounting for $14 \%$ of all cancer deaths [1]. Most of these fatalities can be attributed to metastatic spread of aggressive forms of breast cancer. Frequent sites of distant breast cancer relapse include the livers, pleural membranes, lungs, lymph nodes and brain with a median time of survival of 2.2 to 0.5 years, depending on subtype [2].

(C) 2014 Elsevier B.V. All rights reserved.

"Corresponding Author: Division of Molecular Pharmaceutics and Center of Nanotechnology in Drug Delivery, Eshelman School of Pharmacy, University of North Carolina at Chapel Hill, Chapel Hill, NC 27599, USA. Tel.: +1 919843 0736; fax: +1 9199660197. leafh@unc.edu.

Publisher's Disclaimer: This is a PDF file of an unedited manuscript that has been accepted for publication. As a service to our customers we are providing this early version of the manuscript. The manuscript will undergo copyediting, typesetting, and review of the resulting proof before it is published in its final citable form. Please note that during the production process errors may be discovered which could affect the content, and all legal disclaimers that apply to the journal pertain. 
Anthracyclines and taxanes have shown promising results against breast cancer.

Shortcomings of conventional chemotherapy include (1) severe side effects due to lack of targeting. For example, combined treatment with adriamycin, cyclophosphamide and paclitaxel (ACP group) frequently induces peripheral neurophathy [3]. Paclitaxel kills without distinguishing carcinoma cells from normal cells; (2) conventional chemotherapy relies on excipients to solubilize the drugs, failing to promote specific accumulation of drugs within the tumor to enhance bioavailability. Trastuzumab (Herceptin $\left.{ }^{\circledR}\right)$, approved in 1998 for the treatment of human epidermal growth factor receptor 2 (HER2)-positive breast cancer, opened the door to the application of specific targeting molecules to improve the effectiveness of treatment [4,5]. The discovery of candidate molecular, therapeutic targets led to a focus on RNA interference via small interfering RNA (siRNA) and small noncoding microRNA. This paper will focus only on siRNA (for a microRNA review see [6]).

\subsection{Therapeutic potential of gene silencing by siRNA}

siRNAs are double-stranded RNA molecules with each strand composed of 21-23 nucleotides, $7.5 \mathrm{~nm}$ long and $2 \mathrm{~nm}$ in diameter [7]. siRNA is synthesized and incorporated into an RNA-induced silencing complex (RISC) and then cleaved into a single sense strand and an antisense strand within the RISC. The activated RISC hybridizes specifically with its complementary mRNA target and triggers its degradation by Argonaute 2, depleting the cell of the gene product and its biological functions. Since the first report of its ability to induce homology-dependent mRNA degradation [8] and award of the 2006 Nobel Prize, it has aroused great interest in the potential to knock out expression of disease-causing genes. Advantages of siRNA over other small molecule drugs include its high degree of specificity, capacity to inhibit nearly any target of interest, and simple and rapid design, synthesis and purification [9].

siRNA has shown promising results as a therapeutic agent for brain injury, infection, cancer, HIV, diabetes and neurodegenerative disorders [10-12]. For example, a single intracerebroventricular injection of a new type of naked siRNA, Accell siRNA, leads to neuron-specific protein knockdown in the adult rat brain [13]. After in vivo delivery, Accell siRNA can be targeted with $97 \%$ efficiency to inhibit the expression of two well-known reference proteins, glyceraldehyde 3-phophate dehydrogenase and cyclophilin-B. A number of nanoparticle formulations have also been reported to deliver siRNAs suitable for treatment of neurodegenerative conditions. Low toxicity/high biocompatibility layered double hydroxide nanoparticles internalized by clathrin-dependent endocytosis in neuron cell bodies and dendrites have been used to deliver siRNA to silence neuronal gene expression for the treatment of Huntington's disease [14].

siRNA-based therapies have been effectively applied in the treatment of cancer. Kobayashi et al. used siRNAs to target galectin-3, a multifunctional member of the $\beta$-galactosidebinding protein family, to reduce cellular migration and invasion in an effort to improve pancreatic cancer prognosis and response to chemotherapy. [15]. Specifically, siRNA targeting the forkhead box protein M1 (FoxM1) [16], glioma-associated oncogene 1 (Gli1) [17], transforming growth factor beta (TGF $\beta$ ) and retinoic acid-inducible gene I (RIG-I) [18] were able to induce growth inhibition, epithelial-mesenchymal transition (EMT), and break 
tumor-induced immunosuppression. The potential of siRNA-based therapy in the treatment of other cancers has been demonstrated [19-23].

Challenges remain in the delivery of siRNA for biomedical applications. Unintended reduction of "off-target" genes [24] may require chemical modification and rational siRNA design $[25,26]$. Another challenge is that siRNAs can potentially induce an unwanted innate immune response. Unless RNA-induced immunostimulation is controlled, genetic manipulation and immune activation can be confused [27]. Delivery of siRNA will also require versatile drug carriers to overcome multiple biological barriers [28]: (1) protect siRNA from degradation in the physiological milieu and evade elimination from the reticuloendothelial system (RES, liver sinusoids, the spleen and the alveolar beds of the lung). Carrier size and surface charge strongly influence clearance. Nanoparticles smaller than $100 \mathrm{~nm}$ in diameter are readily targeted to and retained within the tumor. Highly charged particles trigger complement activation, while near neutral particles exhibit reduced phagocytic uptake [29]; (2) allow the siRNA to cross the blood vessel wall. This will require the enhanced permeability and retention (EPR) effect and strategies to overcome unfavorable interstitial pressure within the tumor; (3) allow siRNA to be internalized by tumor cells. High molecular weight (around $13 \mathrm{kDa}$ ), negative charge and hydrophilic properties prevent siRNA from entering cells by passive diffusion [30]. The promising choice to promote cell entry of siRNA is to package it into cationic carriers. A number of targeting moieties, such as small molecules, single-chain monoclonal antibodies and receptors could also be used to mediate endocytosis [31]; (4) allow release siRNA into the cytoplasm. Several strategies have been explored to facilitate cargo escape from the endosomes to reach the cytoplasm. Destabilizing endosomal membranes, induced endosomal swelling and lysis by the proton sponge effect and use of lipid-substituted cationic polymers are possible strategies [32]. Overall, delivery systems are needed to efficiently introduce siRNA into the cytoplasm of specific target cells while avoiding offtarget gene silencing.

This review (1) briefly summarizes the current status of siRNA in the treatment of breast cancer and (2) highlights recent development of liposome, nanoparticle and inorganic materials-based non-viral nanocarriers for siRNA delivery as a means to circumvent the biological barriers to siRNA delivery described above.

\section{2. siRNA for breast cancer therapy}

siRNA has advantages over small molecule drugs based on its specificity to inhibit target gene expression in the cytoplasm with low toxicity [33], providing an efficient way to silence the expression of many oncogenes.

Molecular alterations involved in oncogenesis, survival, proliferation and death of cells, angiogenesis, invasion and metastasis, and resistance to treatment have been characterized in breast cancer. The detail of genes involved is beyond the scope of this review and selective examples are discussed here (Table 1). 


\subsection{Oncogenesis}

About 80 genetic mutations can be found in an individual breast tumor, among which a dozen are thought to be actively driving oncogenesis. Key genes have been identified by screening siRNA/small hairpin RNA libraries $[67,68]$. The oncogene usually mentioned in literature of breast cancer like v-myc myelocytomatosis viral oncogene homolog (c-Myc), murine double minute clone 2 (MDM2) and FoxM1 [69,70]. CCNE2 and MTDH are reported to be associated with metastatic recurrence and poor prognosis [71]. There is a unique spectrum of gene mutations for each patient; therefore the pool of mutant genes is extremely large. The specific targeting capability of siRNA makes personalized treatment for each patient a realistic possibility based on a profile of individual genetic and epigenetic changes [28].

\subsection{Cell cycle and proliferation}

Silencing of specific genes involved in cell cycle regulation can arrest cell division. E2F3 is a transcriptional activator which promotes cell cycle progression due to its overexpression in many bladder, lung and prostate cancers [72, reference for RT-PCR and westerns]. siRNA against $\mathrm{E} 2 \mathrm{~F} 3$ has been shown to block its expression significantly and is a potential therapeutic target in the treatment of breast cancer [38].

Akt1, 2 and 3 each exhibit a specific pattern of subcellular localization (the cytoplasm, mitochondria and nucleus, respectively). Akt2-specific siRNA has been used in MDAMB-231 breast cancer cells to show that Akt2 specifically activates the p70S6K signaling pathway. siRNA silencing of Akt2 expression resulted in cell cycle arrest in G0/G1 due to cyclin-dependent kinase 2 (Cdk2) and cyclin D downregulation. When combined with peroxisome proliferator-activated receptor c coactivator-1a (PGC-1a) upregulation, ablation of Akt2 expression results in an increase in mitochondrial volume [39].

\subsection{Cell death and survival}

Cell death and survival pathways play an important role in cancer progression [4]. Inhibitor of apoptosis proteins ( IAP $^{3}$ ) can directly bind to caspases and block apoptosis. One family member, survivin, has multiple functions including cytoprotection, cell death inhibition, and cell cycle regulation, all of which favor cancer cell survival. Therefore, survivin may be a potential target for anticancer therapy due to its higher levels of expression in carcinoma cells, inhibition of a default apoptotic cascade initiated in mitosis [73] and its relation to angiogenesis [52].

Most drugs become less effective in advanced cancer due to development of drug resistance [74]. MDA435 and MDA231 cells made resistant by chronic exposure to doxorubicin have upregulated expression of Bcl-2, survivin, NFkB and Mcl-1. Treatment of tumor-bearing animals with siRNA against Mcl-1 reduces tumor volume significantly. When siRNA for silencing Ribosomal Protein S6 Kinase was co-delivered, the anti-tumor effect was enhanced in the absence of chemotherapy at the low injection dose of $1.5 \mu \mathrm{g}$ per mouse for intratumoral delivery and $10 \mu \mathrm{g}$ per mouse for intraperitoneal injections [49]. 


\subsection{Angiogenesis}

New blood vessels are essential to support tumor growth beyond a minimal size. An angiogenic switch is thought to be controlled by a balance between pro- and antiangiogenic molecules in the solid tumor microenvironment [75]. When the switch favors angiogenesis, the tumor adopts a phenotype that facilitates the development of mature vessels. Neovascularization is required to supply oxygen and nutrients, remove waste metabolites and is also involved in tumor metastasis. As early as 1971, it was reported that targeting the tumor blood supply by inhibiting angiogenesis led to growth arrest at a diameter of only 2 $\mathrm{mm}[76,77]$. Vascular endothelial growth factor (VEGF), platelet-derived growth factor (PDGF) and transforming growth factor-a (TGF-a) are upregulated in many tumors. Intratumor injection of chitosan/siRNA nanoplexes (siVEGF-A, siVEGFR-1, siVEGFR-2) along with NRP-1 into breast-tumor-bearing rats results in reduction in tumor volumes of up to $97 \%$ [78].

\subsection{Resistance to chemotherapy}

ATP-binding cassette (ABC) transporters are the key component of the energy-dependent efflux system involved in the multidrug-resistant cancer phenotype [79]. The overexpression in breast cancer of an $\mathrm{ABC}$ transporter, $\mathrm{P}$-glycoprotein, is a common mechanism behind a poor chemotherapy response. Silencing of the P-gp encoding gene leads to almost complete restoration of intracellular accumulation of doxorubicin [80,81]. A second type of $\mathrm{ABC}$ transporter is $\mathrm{ABCG} 2$ [82], reported to play an important role in resistance to many drugs, such as leflunomide and teriflunomide [83] and methotrexate and its metabolite [84]. Depending on the different characterization of polymers polyethyleneimine, the delivery of siRNA to down-regulate ABCG2 expression was different. This down-regulation was reported to sensitize the drug-resistant cells to the cytotoxic effects of mitoxantrone by 14fold and the effect persisted for 14 days [85].

\subsection{Invasion and metastasis}

Metastasis causes most cancer deaths and can be described by two phases: (1) the physical translocation of a cancer cell to a distant organ; (2) the development of cancer cells into a secondary tumor at that distant site [86]. Stat3 is usually expressed at high levels in human breast cancers and can correlate with poor prognosis. An activated ErbB2 breast cancer animal model was used to study the role of Stat3 in tumor progression. Stat 3 dramatically affected metastatic progression without altering tumor initiation [87].

Epithelial-mesenchymal transition (EMT) is a highly conserved and fundamental morphogenic process in multicellular organisms and is relevant to the first step in metastasis mentioned above. EMT is characterized by loss of an epithelial phenotype and acquisition of mesenchymal properties. ErbB3 is a member of the epidermal growth factor receptor (EGFR) family and is involved in cell differentiation, migration, proliferation and survival. Knockdown of ErbB3 and Smad2 by siRNA transfection in SK-BR-3 and MCF-7 cells inhibits EMT biomarker expression induced by HRG- $\beta 1$ [63]. 


\section{Recent advances in non-viral delivery vectors for siRNA in the development of breast cancer therapy}

Viral and non-viral delivery systems are used to deliver nucleic acid-based therapies. Viral vector features high gene transfer efficiency but safety concerns have limited their application. For this reason, effort has been focused on the development of non-viral vectors with improved safety and efficacy profiles. Liposome, nanoparticle, and inorganic materialsbased vectors have been considered and studied for gene silencing applications.

\subsection{Liposome based siRNA delivery}

Liposomes and other commercially available transfection reagents like Lipofectamine $®$ and Oligofectamine ${ }^{\circledR}$ have been used extensively for siRNA delivery. Liposomes, composed of an aqueous core enclosed within a phospholipid bilayer, are ideal for the loading of drugs with differing solubilities. Lipophilic agents would localize to the bilayer membrane while hydrophilic agents like genes and siRNA would be entrapped in the core. Long circulation lifetime and high levels of tumor cell uptake can be achieved by modulating the lipid composition, particle size and surface charge of liposomes. Incorporating a poly-(ethylene glycol) (PEG)-lipid conjugate within the lipid bilayer extends retention in circulation and reduces uptake by the mononuclear phagocyte system [88,89]. Specific ligands and antibodies can be conjugated to the lipid to enhance the specificity of targeted delivery $[90,91]$. Examples of liposomal siRNA delivery systems applied in breast cancer therapy are listed in Table 2.

3.1.1 Cationic liposomes-Cationic liposomes are extensively used for siRNA delivery as a means of protecting siRNA against enzymatic degradation, facilitating tumor cell uptake, and promoting escape from the endosomal compartment, resulting in effective cytoplasmic delivery. In fact, the most challenging part in siRNA delivery is how to get the siRNA out of the endosomes intactly, which requires both endosomes escape and sufficient de-assembling of the formulation. The overall endosome escape mechanism for liposomes delivery is shown in Fig. 1.

COX-2-specific siRNA has been encapsulated into DOTAP/DOPE/DOPE-PEG2000 (3:0.95:0.05 molar ratio) cationic liposomes along with MR contrast agents. These liposomes were internalized within $0.5 \mathrm{~h}$ and were detectable within the tumor for at least 24 $\mathrm{h}$ post-injection [64].

PEGylation stabilizes liposomes and prolongs their plasma circulation time [106]. Preparation of a cationic liposomal drug delivery system (DC-chol/DSPC/DSPE-PEG2000) features two PEGylation steps: pre- and post-siRNA insertion. The second PEGylation step significantly increased siRNA circulation by two fold compared with the single PEGylation step. This formulation could be used to downregulate luciferase mRNA expression by more than $50 \%$ [97].

The well-established LPD (liposome-polycation-DNA complex) delivers siRNA efficiently to tumor cells with specific targeting ligands [94]. Optimized LPD was conjugated with antiEGFR Fab' as the tumor specific antibody. The resulting targeted LPD possessed a small 
size of about $150 \mathrm{~nm}$ and enhanced binding affinity, which led to improved gene silencing activity.

Specific peptides are potentially able to target liposomes to breast cancer tumors. The F3 peptide is specifically internalized by cancer cells and endothelial cells of the tumor vasculature. Sterically stabilized liposomes composed of DODAP/DSPC were modified by F3 peptide and were found to encapsulate, protect and effectively deliver siRNA to breast cancer cells and the tumor microenvironment [99].

Cationic liposomes have had only modest success as a delivery vehicle for siRNA, primarily due to issues with toxicity. Cationic liposomes interact with negatively-charged cellular components (opsonins, serum protein and enzymes) resulting in hemolysis [107]. Cationic lipids also activate the complement system and undergo rapid clearance by the MPS as in the case of DOTAP, taken up preferentially by the spleen and liver [108]. Hepatotoxicity and weight loss have also been observed in mice after systemic administration of cationic siRNA nanoparticles [109].

3.1.2 Anionic liposomes-Besides using any cationic lipids or polymers [110,111], divalent cations, such as calcium, have been used to prepare anionic lipid-siRNA complexes. The formulation composed of 4: 6 DOPG/DOPE, $1 \mu \mathrm{g} \cdot \mathrm{mL}^{-1}$ lipid, $2.4 \mathrm{mM} \mathrm{Ca}^{2+}$ and $10 \mathrm{nM}$ siRNA exhibited up to $70 \%$ protein knockdown without cytotoxicity in vitro. DOPE facilitated endosomal escape of cargo while the positively charged calcium ions promoted complex formation between the anionic liposomes and negatively charged siRNA [102].

3.1.3 Neutral liposomes-Neutral liposomes have been developed with lower toxicity, longer circulation time, and reduced interaction with proteins in mind [112]. DOPC-based liposomes developed for PELP1 siRNA delivery have been shown to effectively downregulate target genes and reduce tumor size of estrogen receptor-positive xenograftbased breast tumors by $58.6 \%$ [101].

\subsection{Nanoparticle based siRNA delivery}

Nanoparticles are solid particles with a diameter in the range of 10-1000 nm. They can improve the pharmacokinetic, pharmacodynamic, biodistribution and targeting of therapeutics. Particle size is the most important factor in nanoparticle delivery of siRNA. Diameters larger than $100 \mathrm{~nm}$ are preferentially recognized by the RES, leading to short half-life in circulation. $20-40 \mathrm{~nm}$ nanoparticles are better suited for siRNA delivery [113,114].

Like with liposome based delivery systems, cationic lipids are promising for their therapeutic potential as a transfection vector. Cationic ethylphosphatidylcholines (ePCs) are slowly metabolized and exhibit low toxicity. Dimyristoleoyl-ePC (C14) nanoparticles were complexed with GFP siRNA in MCF-7 cells and exhibited an efficacy exceeding that of Lipofectamine ${ }^{\circledR}$ RNAiMAX [115]. Another cationic lipid dimethyldioctadecylammonium (DDAB) was used to prepare cationic nanoparticles with heat-activated human serum albumin (HSA) as a coating material and D-a-tocopheryl polyethylene glycol 1000 succinate (TPGS) as a hydrophilic surfactant to increase transfection efficiency [116]. 
Cationic biodegradable and biocompatible polymers have been used for their ability to complex with negatively charged siRNA to form nanoparticles by electrostatic interaction. Polyethylenimine (PEI) is one of the most extensively used cationic polymers for siRNA delivery. It can be synthesized with different molecular weights, be linear or branched, and be substituted with various functionalized groups. By the "proton sponge effect", PEIs have a buffering capability in the low $\mathrm{pH}$ environment of the endosome and finally release cargo into cytoplasm [117]. The higher the density of positively charged amino groups in PEI, the stronger the interaction with negatively charged phosphate groups of RNA and the stronger the protection of siRNA from degradation. However, PEI has been reported to induce necrosis or apoptosis. The toxicity of PEI tends to increase with higher molecular weight and increased branching [118]. Therefore, low molecular weights PEIs $(<5 \mathrm{kDa})$ are supposed to have a more acceptable toxicity profile when compared with high molecular weight PEIs (>25 kDa). For more effective siRNA delivery, PEIs with low molecular weight were designed to be substituted with a range of fatty acids with varying chain length (from C8-C18). The resulting lipopolymers showed a significant capability for cellular delivery of BCRP-specific siRNA. The levels of siRNA uptake and protein down-regulation were generally higher with a higher level of lipid substitution [85]. The lipid-substituted polymer can also be used to co-deliver siRNA simultaneously, and the resulting nanoparticles showed a more potent response in drug-resistant breast cancer models ( $\mathrm{p}<0.05 \mathrm{vs}$. scrambled siRNA) [49].

Aside from lipid-substitution, the transfection problem with low molecular PEI can be addressed by conjugation between PEI and the neutral lipid DOPE. The resulting small micelle-like nanoparticles also had improved biocompatibility properties. This hybrid preparation carrying P-gp siRNA led to a twofold increase in doxorubicin uptake and an improvement in the therapeutic effects of doxorubicin on resistant cells $[119,120]$.

A biodegradable triblock copolymer poly(ethylene glycol)-b-poly(e-caprolactone)-b-poly(2aminoethyl ethylene phosphate) (mPEG-b-PCL-b-PPEEA) were designed to self-assemble into micellar nanoparticles, with PCL as the hydrophobic core, PPEEA as the cationic shell and PEG as the hydrophilic corona. This micelleplex can simultaneously delivery Plk1 specific siRNA and paclitaxel into the same tumor cells both in vitro and in vivo and exhibited synergistic tumor suppression effect following systemic administration [34].

Lipid-polymer hybrid nanoparticles were also studied with chemoresistant breast cancer cells. Hydrophobic, hexadecylated PEI was complexed with siRNA and the complexes were then encapsulated by lipid components (tripalmitin, cholesterol, DSPE, DSPE-PEG) and coated with apolipoprotein. The resulting nanoparticles can efficiently serve as a megalintargeting device for enhanced siRNA delivery [58].

Another class of nanoparticles based on biodegradable chitosan was developed for siRNA delivery [78]. Chitosan and its derivatives have been considered as a promising siRNA transporter with low toxicity, good biodegradability and biocompatibility. Low molecular weight chitosan condensed siRNA has the highest cell permeability in comparison with medium molecular weight chitosan and Lipofectamine ${ }^{\circledR}$. Conjugating a phosphorylatable 
short peptide with chitosan can promote intracellular siRNA unpacking in the cytoplasm and improve target gene silencing.

Fluorescent quantum dots (QDs) have been used to study the internalization behavior of nanoparticles. Chitosan nanoparticles with encapsulated quantum dots were synthesized for delivering HER2/neu siRNA. The presence of fluorescent quantum dots showed that the delivery of siRNA to SK-BR-3 breast cancer cells is specific with chitosan/QD nanoparticles [121].

Nanocapsules are also used as a non-viral nanoparticle-based delivery system. They are similar in construction and function to liposomes, which are self-assembled structures formed from amphiphilic block copolymers in aqueous solution, such as diblock polymer poly(1,2-butadiene)-b-poly(ethyleneoxide) (PB-PEO) [122], PEG- $\varepsilon$-caprolactone-malic acid (PEG-PCL/MA) [123].

An alternative strategy for in vivo siRNA delivery is direct conjugation of siRNA with specific targeting molecules for cellular delivery. In some studies, siRNA delivery was enhanced at the cellular level when siRNAs were administered as covalent conjugates with cell penetrating peptides (CPPs) [118]. CPPs are composed of short amino acid sequences that can complex with nucleic acids into nanoparticles and achieve efficient cellular uptake. The major CPPs studied include: penetratin, transportan, TAT, poly-arginine and amphipathic peptide [124,125]. A TAT-derived cell-penetrating peptide arginine-9 (R9) was chosen to carry siRNA against the connective tissue growth factor (CTGF) for breast cancer treatment [126]. PR39 can also deliver siRNA into cell cytoplasm by penetrating cell membranes rapidly for its proline and arginine rich composition [61].

\subsection{Inorganic materials}

3.3.1 Metallic oxide nanoparticles-Magnetic nanovectors for effective intracellular delivery of siRNA provide a safe alternative to the highly cationic vectors of PEI or PAMAM by using a penetrating peptide, poly-arginine (pArg), as a coating material. Amine terminated PEG-coated iron oxide nanoparticles with $12 \mathrm{~nm}$ core diameter were coated with PEI, pArg and polylysine (pLys). For MCF7/GFP ${ }^{+}$cells, the pArg coating nanoparticles were the most efficient and least toxic when compared with the other two coating polymers [127].

Recently, hollow manganese oxide nanoparticles have been used as MRI contrast agents because of their suitable characteristics for cellular and molecular imaging application. Biomedical application, however, requires the surface of these nanoparticles to be modified in order to achieve good pharmacological properties. PEI-coated hollow manganese oxide nanoparticles were developed for HER2-overexpressing human breast cancer to target VEGF expression with siRNA. DOPA was utilized as a robust anchor for surface immobilization of PEI on the particles, and the particles were still functionalized by Herceptin. Herceptin-mediated targeting greatly increased intracellular delivery and the therapeutic effects of VEGF siRNA against the cancer cells [128]. 
3.3.2 Gold nanoparticles-Gold nanoparticles are ideal for cell imaging due to ease of preparation and bioconjugation, high contrast, large absorption coefficients and noncytotoxicity. They can be tailored to a specific size and shape and can be modified with thiolated molecules to become gene carriers $[129,130]$. There are concerns that gold nanoparticles would exert concentration-dependent cytotoxicity and upregulation of mRNA expression of p53, caspase-3 and so on in human breast epithelial MCF-7 cells [131].

To construct siRNA delivery systems, poly(allylamine hydrochloride) (PAH), PEI and poly(diallyl dimethyl ammonium chloride) (PDDA), and siRNA were assembled on the surface of gold nanoparticles, respectively, by the ionic layer-by-layer method. After stabilization by denatured bovine serum albumin, the EGFR siRNA delivered by PAHmodified gold nanoparticles exhibited an improved silencing effect when compared to Lipofectamine 2000® [132].

3.3.3 Silica nanoparticles-Silica nanoparticles have been explored as a tumor-targeting delivery system. Aside from low immunogenicity and ability to be endocytosed by cells, silica nanoparticles can also control loading efficiency and release profile by adjusting surface area, pore volume and structure [133]. Porous silica nanoparticles, especially, possess a range of mesoporous structures. Well-functionalized silica nanoparticles have been harnessed as a potential biocompatible drug/gene delivery vehicle [134]. They have been functionalized with Herceptin ${ }^{\circledR}$, targeting HER2, which is overexpressed in breast cancer [135]. To overcome chemotherapy resistance in breast cancer, $50 \mathrm{~nm}$ mesoporous silica nanoparticles have been functionalized with PEI-PEG copolymers to provide protected delivery of attached doxorubicin and P-gp siRNA to the tumor site. Up to $8 \%$ of the injected dose was retained in the tumor and dual delivery by this particle could achieve synergistic inhibition of tumor growth [136]. The multistage vector (MSV) based on silicon particle is also developed comprising of nanoporous silicon microparticles (first-stage particles) loaded with drug-incorporated nanoparticles (second-stage particles). For example, liposomal-encapsulated, gene-specific ATM siRNA was loaded into porous silicon. Biweekly treatment of MSV/ATM suppressed ATM expression in tumor tissues, and consequently inhibited growth of MDA-MB-231 orthotopic tumor in nude mice [45].

3.3.4 Carbonate apatite nanoparticles- $\mathrm{pH}$-sensitive carbonate apatite nanoparticles are getting attention because of their biodegradability and resemblance to body hard tissue components. Because of their high affinity interactions with siRNA and desirable size for endocytosis, carbonate apatite nanoparticles efficiently deliver siRNA into cells. With a fast dissolution profile in the acidic endosomal environment for efficient cargo release, carbonate apatite appears to be a promising tool for therapeutic delivery [137-139]. Carbonate apatite-mediated delivery of the siRNAs targeting ABCG2 and ABCB1 gene transcripts resulted in a robust increase in chemosensitivity of therapy resistant breast cancer cells [140]. Carbonate apatite also facilitates the intracellular delivery of c-ROS1 siRNA to sensitize MCF-7 breast cancer cells to cisplatin and paclitaxel, resulting in increased cell killing in comparison to chemotherapy drugs used alone [141].

3.3.5 Carbon nanotubes-Carbon nanotubes (CNTs) are cylindrical molecules composed of carbon atoms organized in thin graphite sheets of condensed benzene rings 
rolled up into a seamless, hollow cylinder. CNTs are considered as potential nano drug delivery vectors due to prolonged circulation time, ease of crossing cell membranes, and translocation directly into the cytoplasm of target cells by an endocytosis-independent mechanism without inducing cell death $[142,143]$. Their distinctive length-to-diameter ratio and surface properties make them promising candidates as molecular transport systems [144]. CNTs are divided into four categories according to their diameter, length and presence of walls: (1) single-walled carbon nanotubes (SWCNTs), (2) double-walled carbon nanotubes, (3) triple-walled carbon nanotubes and (4) multi-walled carbon nanotubes. For many applications, it is necessary to tailor the outer surface of CNTs to take advantage of their unique properties. SWNTs with suitable size are potential anticancer drug carriers after being properly functionalized [145]. A novel strategy for chemically functionalized SWNTs involves nanotubes with a diameter of $0.8-1.2 \mathrm{~nm}$ and length of $100-1000 \mathrm{~nm}$ functionalized with DSPE-PEG-Amine and connected to MDM2 siRNA by disulfide bonds. These can be successfully introduced into breast carcinoma cells and inhibit proliferation by $44 \%$ and induce apoptosis in $30 \%$ of the tumor cells [69].

\section{Future perspectives}

Since siRNA offers advantages over traditional pharmaceutical drugs, breast cancer therapy will continue to benefit from the discovery of novel molecular targets. However, siRNA delivery remains a challenge, partly due to the instability of siRNA and its inability to cross cellular membranes. To realize the possible delivery siRNA based therapies, further research must focus on (1) specific target genes involved in tumorigenesis and progression of breast cancer plus rules governing siRNA effectiveness and selectivity; (2) Various non-viral nanocarriers have been reported to provide promising application in siRNA delivery in vitro and in vivo, such as liposomes, nanoparticles and inorganic materials. Although significant advancement has been made in the field of siRNA delivery, there is still a need to explore alternative effective strategies. The delivery system should be nontoxic, non-immunogenic, and sufficient for siRNA protection, to reach the target cell and facilitate cell uptake, to release siRNA into the cytoplasm to achieve gene silencing; (3) after injection of siRNA, pharmacokinetic profile and siRNA distribution in organs and tumors are not well investigated in many studies. Florescence and inorganic materials like gold, QDs and metallic oxide are used for in situ distribution analysis. The siRNA in the organ cells, tumor cells and stroma cells are not known. A suitable analytical method should be developed for detailed and accurate evaluation of siRNA delivery at varying time points and in different tissues.

\section{Acknowledgments}

This project was supported by NIH grants CA129835, CA129421, CA151652, CA151455 and CA149363. We thank Steven Plonk for editing the manuscript.

\section{References}

1. Siegel R, Naishadham D, Jemal A. Cancer statistics 2012. CA Cancer J. Clin. 2012; 62:10-29. [PubMed: 22237781] 
2. Kennecke H, Yerushalmi R, Woods R, Cheang MCU, Voduc D, Speers CH, Nielsen TO, Gelmon K. Metastatic behavior of breast cancer subtypes. J. Clin. Oncol. 2010; 28:3271-3277. [PubMed: 20498394]

3. Kim WY, Woo SU, Seo JH, Son GS, Lee JB, Bae JW. Toxicities, dose reduction and delay of docetaxel and paclitaxel chemotherapy in breast cancer without distant metastases. J. Cancer Res. Therap. 2011; 7:412-415. [PubMed: 22269401]

4. Hanahan D, Weinberg RA. Hallmarks of cancer: the next generation. Cell. 2011; 144:646-674. [PubMed: 21376230]

5. Blanco E, Ferrari M. Emerging nanotherapeutic strategies in breast cancer. The Breast. 2014; 23:10-18. [PubMed: 24215984]

6. Wang V, Wu W. MicroRNA: a new player in breast cancer development. J. Cancer Mol. 2007; 3:133-138.

7. Sinden, RR.; Pearson, CE.; Potaman, VN.; Ussery, DW. DNA: structure and function in advances in genome biology. first ed. Greenwich: Jai Press Inc; 1998.

8. Fire A, Xu S, Montgomery MK, Kostas SA, Driver SE, Mello CC. Potent and specific genetic interference by double-stranded RNA in Caenorhabditis elegans. Nature. 1998; 391:806-811. [PubMed: 9486653]

9. Sah DWY. Therapeutic potential RNA interference for neurological disorders. Life science. 2006; 79:1773-1780.

10. Fukuda AM, Badaut J. siRNA Treatment: "a sword-in-the-stone" for acute brain injuries. Genes. 2013; 4:435-456. [PubMed: 24705212]

11. Bakhtiyari S, Haghani K, Basati G, Karimfar MH. siRNA therapeutics in the treatment of diseases. Ther. Deliv. 2013; 4:45-57. [PubMed: 23323780]

12. Burnett JC, Rossi JJ. RNA-based therapeutics: Current progress and future prospects. Chem. Biol. 2012; 19:60-71. [PubMed: 22284355]

13. Nakajima H, Kubo T, Semi Y, Itakura M, Kuwmura M, Izawa T, Azuma YT, Takeuchi T. A rapid, targeted, neuron-selective, in vivo knockdown following a single intracerebroventricular injection of a novel chemically modified siRNA in the adult rat brain. J. Biotechnol. 2012; 157:326-333. [PubMed: 22079868]

14. Wong YY, Markham K, Xu ZP, Chen M, Lu GQ, Bartlett PF, Cooper HM. Efficient delivery of siRNA to cortical neurons using layered double hydroxide nanoparticles. Biomaterials. 2010; 31:8770-8779. [PubMed: 20709387]

15. Kobayashi T, Shimura T, Yajima T, Kubo N, Araki K, Tsutsumi S, Suzuki H, Kuwano H, Raz A. Transient gene silencing of galectin-3 suppresses pancreatic cancer cell migratin and invasion through degradation of $\beta$-catenin. Int. J. Cancer. 2011; 129

16. Wang ZW, Ahmad A, Banerjee S, Azmi A, Kong D, Li YW, Sarkar FH. FoxM1 is a novel target of a natural agent in pancreatic cancers. Pharm. Res. 2010; 27:1159-1168. [PubMed: 20354770]

17. Guo JF, Gao J, Li ZS, Gong YF, Man XH, Jin J, Wu H. Adenovirus vector-mediated Gli1 siRNA induces growth inhibition and apoptosis in human pancreatic cancer with Smo-dependent or Smoindependent Hh pathway activation in vitro and in vivo. Cancer Letters. 2013; 339:185-194. [PubMed: 23791879]

18. Schnurr M, Duewell P. Breaking tumor-induced immunosuppression with 5'-triphosphate siRNA silencing TGF $\beta$ and activating RIG-I. Oncolmmunology. 2013; 2:e24170-e24173.

19. Kuphal S, Wallner S, Bosserhogff AK. Impact of LIF (leukemia inhibitory factor) expression in malignant melanoma. Exp. Mol. Pathol. 2013; 95:156-165. [PubMed: 23831429]

20. Taratula O, Kuzmov A, Shah M, Garbuzenko OB, Minko T. Nanostructured lipid carriers as multifunctional nanomedicine platform for pulmonary co-delivery of anticancer drugs and siRNA. J. Control. Release. 2013; 171:349-357. [PubMed: 23648833]

21. Lee S, Yoon CY, Byun SS, Lee E, Lee SE. The role of c-FLIP in cisplatin resistance of human bladder cancer cells. J. Urol. 2013; 18:2327-2334. [PubMed: 23313194]

22. Zheng Y, Wang Z, Bie W, Brauer PM, Perez WBE, Li J, Moqueira V, Raychaudhuri P, Hay N, Tonetti DA, Macias V, Kajdacsy-Balla A, Tyner AL. PTK6 activation at the membrane regulates epithelial-mesenchymal transition in prostate cancer. Cancer Res. 2013; 73:5426-5437. [PubMed: 23856248] 
23. Goldberg MS. SiRNA delivery for the treatment of ovarian cancer. Methods. 2013; 63:95-100. [PubMed: 23403216]

24. Jackson AL, Bartz SR. Expression profiling reveals off-target gene regulation by RNAi. Nat. Biotech. 2003; 21:635-637.

25. Kenski DM, Butora G, Willingham AT, Cooper AJ, Fu WL, Qi N, Soriano F, Davies IW, Flanagan WM. siRNA-optimized modifications for enhanced in vivo activity. Mol. Ther. Nucleic Acids. 2012; 1:e5. [PubMed: 23344622]

26. Petri S, Meister G. siRNA design principles and off-target effects. Mothods Mol. Biol. 2013; 986:59-71.

27. Whitehead KA, Kahlman JE, Langer RS, Anderson DG. Silencing or stimulation? siRNA delivery and the immune system. Annu. Rev. Chem. Biomol. Eng. 2011; 2:77-96. [PubMed: 22432611]

28. Shen HF, Mittal V, Ferrari M, Chang J. Delivery of gene silencing agents for breast cancer therapy. Breast Cancer Res. 2013; 15:205-212. [PubMed: 23659575]

29. Reischl D, Zimmer A. Drug delivery of siRNA therapeutics: potentials and limits of nanosystems. Nanomedicine: Nonotec. Biol. Med. 2009; 5:8-20.

30. Bumcrot D, Manoharan M, Koteliansky V, Sah DW. RNAi therapeutics: a potential new class of pharmaceutical drugs. Nat. Chem. Biol. 2006; 2:711-719. [PubMed: 17108989]

31. Zhang HM, Su Y, Guo SC, Yuan J, Lim T, Liu J, Guo PX, Yang DC. Targeted delivery of anticoxsackievirus siRNAs using ligand-conjugated packaging RNAs. Antiviral Res. 2009; 83:307-316. [PubMed: 19616030]

32. Guo ST, Huang L. Nanoparticles escaping RES and endosome: challenges for siRNA delivery for cancer therapy. J. Nanomaterials. 2011:12. article ID 7428952011.

33. Bennett CF, Swayze EE. RNA targeting therapeutics: molecular mechanisms of antisense oligonucleotides as a therapeutic platform. Annu. Rev. Pharmacol. 2010; 50:259-293.

34. Sun TM, Du JZ, Yao YD, Mao CQ, Dou S, Huang SY, Zhang PZ, Leong KW, Song EW, Wang J. Simultaneous delivery of siRNA and paclitaxel via a "two-in-one" micelleplex promotes synergistic tumor suppression. ACS Nano. 2011; 5:1483-1494. [PubMed: 21204585]

35. Yang XZ, Dou S, Sun TM, Mao CQ, Wang HX, Wang J. Systemic delivery of siRNA with cationic lipid assisted PEG-PLA nanoparticles for cancer therapy. J. Control. Release. 2011; 156:203-211. [PubMed: 21839126]

36. Jordan VC, Brodie AM. Development and evolution of therapies targeted to the estrogen receptor for the treatment and prevention of breast cancer. Steroids. 2007; 71:7-25. [PubMed: 17169390]

37. Bouclier C, Moine L, Hillaireau H, Marsaud V, Connault E, Opolon P, Couvreur P, Fattal E, Renoir JM. Physicochemical characteristics and preliminary in vivo biological evaluation of nanocapsules loaded with siRNA targeting estrogen receptor alpha. Biomacromolecules. 2008; 9:2881-2890. [PubMed: 18788777]

38. Vimala K, Sundarraj S, Sujitha MV, Kannan S. Curtailing overexpression of E2F3 in breast cancer using siRNA (E2F3)-based gene silencing. Arch. Med. Res. 2012; 43:415-422. [PubMed: 22960857]

39. Santi SA, Lee H. Ablation of Akt2 induces autophagy through cell cycle arrest, the downregulation of p70S6K, and the deregulation of mitochondria in MDA-MB231 Cells. PLoS ONE. 2011; 6:e14614. [PubMed: 21297943]

40. Thornburg JM, Nelson KK, Clem BE, Lane AN, Arumugam S, Simmnos A, Eaton JW, Telang S, Chesney J. Targeting aspartate aminotransferase in breast cancer. Breast Cancer Res. 2008; 10:R84. [PubMed: 18922152]

41. Dou S, Yao YDD, Yang XZ, Sun TM, Mao CQ, Song EW, Wang J. Anti-Her2 single-chain antibody mediated DNMTs-siRNA delivery for targeted breast cancer therapy. J. Control. Release. 2012; 161:875-883. [PubMed: 22762887]

42. Pillé JY, Li H, Blot E, Bertrand JR, Pritchard LL, Opolon P, Maksimenko A, Lu H, Vannier JP, Soria J, Malvy C, Soria C. Intravenous delivery of anti-RhoA small interfering RNA loaded in nanoparticles of chitosan in mice. Hum. Gene Ther. 2006; 17:1019-1026. [PubMed: 17007568]

43. Pille JY, Denoyelle C, Varet J, Bertrand JR, Soria J, Opolon P, Lu H, Pritchard LL, Vannier JP, Malvy C, Soria C, Li H. Anti-RhoA and anti-RhoC siRNAs inhibit the proliferation and 
invasiveness of MDA-MB-231 breast cancer cells in vitro and in vivo. Mol. Ther. 2005; 11:267274. [PubMed: 15668138]

44. Faouzi M, Haque F, Potier M, Ahidouch A, Sevestre H, Ouadid-Ahidouch H. Down-regulation of Orai3 arrests cell-cycle progression and induces apoptosis in breast cancer cells but not in normal breast epithelial cells. J. Cell Physiol. 2011; 226:542-551. [PubMed: 20683915]

45. Xu R, Huang Y, Mai J, Zhang G, Guo X, Xia X, Koay EJ, Qin G, Erm DR, Li Q, Liu X, Ferrari M, Shen $\mathrm{H}$. Multistage vectored siRNA targeting ataxia-telangiectasia mutated for breast cancer therapy. Small. 2013; 9:1799-1808. [PubMed: 23293085]

46. Miani-Tehrani A, Jiang HL, Kim YK, Chung YS, Yu KN, Kim JE, Shin JY, Hong SH, Lee JH, Kim SH, Chang HJ, Park S, Kang BN, Cho CS, Cho MH. Suppression of tumor growth in xenograft model mice by small interfering RNA targeting osteopontin deloivery using biocompatible poly (amino ester). Int. J. Pharm. 2012; 431:197-203. [PubMed: 22531848]

47. Faltus T, Yuan J, Zimmer B, Krämer A, Loibl S, Kaufmann M, Strebhardt K. Silencing of the HER2/neu gene by siRNA inhibits proliferation and induces apoptosis in HER2/neuoverexpressing breast cancer cells. Neoplasia. 2004; 6:786-795. [PubMed: 15720805]

48. Pan M, Wei QJ, Cao F, Lu YJ, Zhu YB, Shu YQ, Cao X. Inhibition of cell proliferation by siRNA targeting hPRLR in breastcancerMCF-7 cell line. JNMU. 2007; 21:372-376.

49. Aliabadi HM, Maranchuk R, Kucharski C, Mahdipoor P, Hugh J, Uludağ H. Effective response of doxorubicin-sensitive and -resistant breast cancer. J. Control. Release. 2013; 172:219-228. [PubMed: 23994345]

50. Thiel KW, Hernandez LI, Dassie JP, Thiel WH, Liu X, Stockdale KR, Rothman AM, Hernandez FJ, McNamara JO 2nd, Giangrande PH. Delivery of chemo-sensitizing siRNA to HER2 ${ }^{+}$-breast cancer cells using RNA aptamers. Nucleic Acids Res. 2012; 40:6319-6337. [PubMed: 22467215]

51. Montazeri AH, Landry B, Mahdipoor P, Uludağ H. Induction of apoptosis by surviving silencing through siRNA delivery in a human breast cancer cell line. Mol. Pharm. 2011; 8:1821-1830. [PubMed: 21838308]

52. Ryan BM, O’Donovan N, Duffjy MJ. Survivin: a new target for anti-cancer therapy. Cancer Treat. Rev. 2009; 35:553-562. [PubMed: 19559538]

53. Dougherty CJ, Ichim TE, Liu L, Reznik G, Min WP, Ghochikyan A, Agadjanyan MG, Reznik BN. Selective apoptosis of breast cancer cells by siRNA targeting of BORIS. Biochem. Biophys. Res. Commun. 2008; 370:109-112. [PubMed: 18355444]

54. Bae KH, Lee K, Lee J, Lee IS, Lee JH, Park TG. Surface functionalized hollow manganeses oxide nanoparticles for cancer targeted siRNA delivery and magnetic resonance imaging. J. Control. Release. 2011; 152:e133-e134. [PubMed: 22195802]

55. Qin XY, Wei F, Yoshinaga J, Yonemoto J, Tanokura M, Sone H. siRNA-mediated knockdown of aryl hydrocarbon receptor nuclear translocator 2 afftects hypoxia-inducible factor-1 regulatory signaling and metabolism in human breast cancer cells. FEBS Lett. 2011; 585:3310-3315. [PubMed: 21945317]

56. Li XY, Kong XN, Wang Y, Yang QF. 53BP1 is a novel regulator of angiogenesis in breast cancer. Cancer Sci. 2013

57. Jiang J, Yang SJ, Wang JC, Yang LJ, Xu ZZ, Yang T, Liu XY, Zhang Q. Sequential treatment of drug-resistant tumors with RGD-modified liposomes containing siRNA or doxorubicin. Eur. J. Pharm. Biopharm. 2010; 76:170-178. [PubMed: 20600887]

58. Xue HY, Wong HL. Targeting megalin to enhance delivery of anti-clusterin small-interfering RNA nanomedicine to chemo-treated breast cancer. Eur. J. Pharm. Biopharm. 2012; 81:24-32. [PubMed: 22369881]

59. Honma K, Iwao-Koizumi K, Takeshita F, Yamamoto Y, Yoshida T, Nishio K, Nagahara S, Kato K, Ochiya T. RPN2 gene confers docetaxel resistance in breast cancer. Nat. Med. 2008; 14:939 948. [PubMed: 18724378]

60. Meryet-Fiquières M, Resina S, Lavigne C, Barlovatz-Meimon G, Lebleu B, Thierry AR. Inhibition of PAI-1 expression in breast cancer carcinoma cells by siRNA at nanomolar range. Biochimie. 2007; 89:1228-1233. [PubMed: 17509745] 
61. Tian W, Li B, Zhang X, Dang W, Wang X, Tang H, Wang L, Cao H, Chen T. Suppression of tumor invasion and migration inbreast cancer cells following delivery of siRNA against Stat 3 with the antimicrobial peptide PR39. Oncol. Rep. 2012; 28:1362-1368. [PubMed: 22797782]

62. de Graauw M, van Miltenburg MH, Schmidt MK, Pont C, Lalai R, Kartopawiro J, Pardali E, Le Dévédec SE, Smit VT, van der Wal A, Van't Veer LJ, Cleton-Jansen AM, ten Dijke P, van de Water B. Annexin A1 regulates TGF- $\beta$ signaling and promotes metastasis formation of basal-like breast cancer cells. Proc. Natl. Acad. Sci. USA. 2010; 107:6340-6345. [PubMed: 20308542]

63. Kim J, Jeong H, Lee Y, Kim C, Kim H, Kim A. HRG- $\beta 1$-driven ErbB3 signaling induces epithelial-mesenchymal transition in breast cancer cells. BMC Cancer. 2013; 13:383. [PubMed: 23937725]

64. Mikhaylova M, Stasinopoulos I, Kato Y, Artemov D, Bhujwalla ZM. Imaging of cationic multifunctional liposome-mediated delivery of Cox-2 siRNA. Cancer Gene Ther. 2009; 16:217226. [PubMed: 18927599]

65. Mierke CT. The integrin alphav beta3 increases cellular stiffness and cytoskeletal remodeling dynamics to facilitate cancer cell invasion. New J. Phys. 2013; 15:015003.

66. Cao Q, Cai WB, Li TF, Yang Y, Chen K, Xing L, Chen XY. Combination of intergrin siRNA and irradiation for breast cancer therapy. Biochem. Biophys. Res. Commun. 2006; 351:726-732. [PubMed: 17087916]

67. Wood LD, Parsons DW, Jones S, Lin J, Sjöblom T, Leary RJ, Shen D, Boca SM, Barber T, Ptak J, Silliman N, Szabo S, Dezso Z, Ustyanksky V, Nikolskaya T, Nikolsky Y, Karchin R, Wilson PA, Kaminker JS, Zhang Z, Croshaw R, Willis J, Dawson D, Shipitsin M, Willson JK, Sukumar S, Polyak K, Park BH, Pethiyagoda CL, Pant PV, Ballinger DG, Sparks AB, Hartigan J, Smith DR, Suh E, Papadopoulos N, Buckhaults P, Markowitz SD, Parmigiani G, Kinzler KW, Velculescu VE. The genomic landscapes of human breast and colorectal cancers. Science. 2007; 318:11081113. [PubMed: 17932254]

68. Schlabach MR, Luo J, Solimini NL, Hu G, Xu Q, Li MZ, Zhao Z, Smogorzewska A, Sowa ME, Ang XL, Westbrook TF, Liang AC, Chang K, Hackett JA, Harper JW, Hannon GJ, Elledge SJ. Cancer proliferation gene discovery through functional genomics. Science. 2008; 319:620-624. [PubMed: 18239126]

69. Chen H, Ma X, Li Z, Shi Q, Zheng W, Liu Y, Wang P. Functionalization of single-walled carbon nanotubes enables efficient intracellular delivery of siRNA targeting MDM2 to inhibit breast cancer cells growth. Biomed. Pharmacother. 2012; 66:334-338. [PubMed: 22397761]

70. Wang M, Gartel AL. The suppression of FOXM1 and its targets in breast cancer xenograft tumors by siRNA. Oncotarget. 2011; 2:1218-1226. [PubMed: 22203467]

71. van't Veer LJ, Dai H, van de Vijver MJ, He YD, Hart AA, Mao M, Peterse HL, van der Kooy K, Marton MJ, Witteveen AT, Schreiber GJ, Kerkhovern RM, Roberts C, Linsley PS, Bernards R, Friend SH. Gene expression profiling predicts clinical outcome of breast cancer. Nature. 2002; 415:530-536. [PubMed: 11823860]

72. Kort JE, Farber L, Tretiakova M, Petillo D, Furge KA, Yang XJ, Cornelius A, The BT. The E2F3oncomir-1 axis is activated in Wilms' tumor. Cancer Res. 2008; 68:4034-4038. [PubMed: 18519660]

73. Kanwar RK, Cheung CH, Chang JY, Kanwar JR. Recent advances in anti-survivin treatments for cancer. Curr. Med. Chem. 2010; 17:1509-1515. [PubMed: 20166933]

74. Agarwal R, Kaye SB. Ovarian cancer: strategies for overcoming resistance to chemotherapy. Nat. Rev. Cancer. 2003; 3:502-516. [PubMed: 12835670]

75. Hanahan D, Folkman J. Patterns and emerging mechanisms of the angiogenic switch during tumorigenesis. Cell. 1996; 86:353-364. [PubMed: 8756718]

76. Kerenidi, T.; Syrigos, K. Angiogenesis: antiangiogenesis strategy and angiogenesis inhibitors. In: Chatterjee, M., editor. Angiogenesis \& Therapeutic Targes In Cancer, Bentham ebooks. 2010. p. 1-2.

77. Fokman J. Tumor angiogenesis: therapeutic implications. N. Engl. J. Med. 1971; 285:1181-1186.

78. Şalva E, Kabasakal L, Eren F, Özkan N, Çakalağaoğlu F, Akbuğa J. Local delivery of chitosan/ VEGF siRNA nanoplexes reduces angiogenesis and growth of breast cancer in vivo. Nucleic Acid Ther. 2012; 22:40-48. [PubMed: 22217324] 
79. Szakács G, Paterson JK, Ludwig JA, Booth-Genthe C, Gottesman MM. Targeting multidrug resistance in cancer. Nat. Rev. Drug Discov. 2010; 5:219-230. [PubMed: 16518375]

80. Guo JF, Bourre L, Soden DM, O’Sullivan GC, O’Driscoll C. Can non-viral technologies knockdown the barriers to siRNA delivery and achieve the next generation of cancer therapeutics? Biotechnol. Adv. 2011; 29:402-417. [PubMed: 21435387]

81. Dönmeza Y, Gündüz U. Reversal of multidrug resistance by small interfering RNA (siRNA) in doxorubicin-resistant MCF-7 breast cancer cells. Biomed. Pharmacother. 2011; 65:85-89. [PubMed: 21237614]

82. Doyle LA, Yang W, Abruzzo LV, Krogmann T, Gao YM, Rishi AK, Ross DD. A multidrug resistance transporter from human MCF-7 breast cancer cells. Proc. Natl. Acad. Sci. USA. 1998; 95:15665-15670. [PubMed: 9861027]

83. Kis E, Nagy T, Jani M, Molnar E, Janossy J, Ujhellyi O, Nemet K, Heredi-Szabo K, Krajcsi P. Leflunomide and its metabolite A771726 are high affinity substrates of BCRP: implications for drug resistance. Ann. Rheum. Dis. 2009; 68:1201-1207. [PubMed: 18397960]

84. Vlaming ML, Pala Z, van Esch A, Wagenaar E, de Waart DR, van de Wetering K, van der Kruijssen CM, Oude Elferink RP, van Tellingen O, Schinkel AH. Functionally overlapping roles of Abcg2 (Bcrp1) and Abcc2 (Mrp2) in the elimination of methotrexate and its main toxic metabolite 7-hydroxymethotrexate in vivo. Clin. Cancer Res. 2009; 15:3084-3093. [PubMed: 19383815]

85. Aliabadi HM, Landry B, Mahdipoor P, Hsu CYM, Uludağ H. Effective down-regulation of breast cancer resistance protein (BCRP) by siRNA delivery using lipid-substituted aliphatic polymers. Eur. J. Pharm. Biopharm. 2012; 81:33-42. [PubMed: 22311298]

86. Chaffer CL, Weinberg RA. Aperspective on cancer cell metastasis. Science. 2011; 331:1559-1564. [PubMed: 21436443]

87. Ranger JJ, Levy DE, Shahalizadeh S, Hallett M, Muller WJ. Identification of a Stat3-dependent transcription regulatory network involved in metastatic progression. Cancer Res. 2009; 69:68236830. [PubMed: 19690134]

88. Fang C, Shi B, Pei YY, Hong MH, Wu J, Chen HZ. In vivo tumor targeting of tumor necrosis factor-[alpha]-loaded stealth nanoparticles: effect of MePEG molecular weight and particle size. Eur. J. Pharm. Sci. 2006; 27:27-36. [PubMed: 16150582]

89. Immordino ML, Dosio F, Cattel L. Stealth liposomes: review of the basic science rationale, and clinical applications, existing and potential. Int. J. Nanomedicine. 2006; 1:297-315. [PubMed: 17717971]

90. Guo P, Coban O, Snead NM, Trebley J, Hoeprich S, Guo S, Shu Y. Engineering RNA for targeted siRNA delivery and medical application. Adv. Drug Deliv. Rev. 2010; 62:650-666. [PubMed: 20230868]

91. Perche F, Torchilin VP. Recent trends in multifunctional liposomal nanocarriers for enhanced tumor targeting. J. Drug Deliv. 2013

92. Chien PY, Wang J, Carbonaro D, Lei S, Miller B, Sheikh S, Ali SM, Ahmad MU, Ahmad I. Novel cationic cardiolipin analogue-based liposome for efficient DNA and small interfering RNA delivery in vitro and in vivo. Cancer Gene Ther. 2005; 12:321-328. [PubMed: 15578064]

93. Bedi D, Musacchio T, Fagbohun OA, Gillespie JW, Deinnocentes P, Bird RC, Bookbinder L, Torchilin VP, Petrenko VA. Delivery of siRNA into breast cancer cells via phage fusion proteintargeted liposomes. Nanomedicine. 2011; 7:315-323. [PubMed: 21050894]

94. Gao J, Liu W, Xia Y, Li W, Sun J, Chen H, Li B, Zhang D, Qian W, Meng Y, Deng L, Wang H, Chen J, Guo Y. The promotion of siRNA delivery to breast cancer overexpressing epidermal growth factor receptor through anti-EGFR antibody conjugation by immunoliposomes. Biomaterials. 2011; 32:3459-3470. [PubMed: 21296406]

95. Lesoon-Wood LA, Kim WH, Kleinman HK, Weintraub BD, Mixson AJ. Systemic gene therapy with p53 reduces growth and metastases of a malignant human breast cancer in nude mice. Hum. Gene Ther. 1995; 6:395-405. [PubMed: 7612697]

96. Zhang Y, Li H, Sun J, Gao J, Liu W, Li B, Guo Y, Chen J. DC-Chol/DOPE cationic liposomes: A comparative study of the influence factors on plasmid pDNA and siRNA gene delivery. Int. J. Pharm. 2010; 390:198-207. [PubMed: 20116418] 
97. Ho EA, Osooly M, Strutt D, Masin D, Yang Y, Yan H, Bally M. Characterization of longcirculating cationic nanoparticle formulations consisting of a two-stage PEGylation step for the delivery of siRNA in a breast cancer tumor model. J. Pharm. Sci. 2013; 102:227-236. [PubMed: 23132529]

98. Lavigne C, Thierry AR. Specific subcellular localization of siRNAs delivered by lipoplex in MCF-7 breast cancer cells. Biochimie. 2007; 89:1245-1251. [PubMed: 17619075]

99. Gomes-da-Silva LC, Santos AO, Bimbo LM, Moura V, Ramalho JS, Pedroso de Lima MC, Simões S, Moreira JN. Toward a siRNA-containing nanoparticle targeted to breast cancer cells and the tumor microenvironment. Int. J. Pharm. 2012; 434:9-19. [PubMed: 22617794]

100. Gao J, Sun J, Li H, Liu W, Zhang Y, Li B, Qian W, Wang H, Chen J, Guo Y. Lyophilized HER2specific PEGylated immunoliposomes for active siRNA gene silencing. Biomaterials. 2010; 31:2655-2664. [PubMed: 20035999]

101. Cortez V, Mann M, Tekmal S, Suzuki T, Miyata N, Rodriguez-Aguayo C, Lopez-Berestein G, Sood AK, Vadlamudi RK. Targeting the PELP1-KDM1 axis as a potential therapeutic strategy for breast cancer. Breast Cancer Res. 2012; 14:R108. [PubMed: 22812534]

102. Kapoor M, Burgess DJ. Efficient and safe delivery of siRNA using anionic lipids: Formulation optimization studies. Int. J. Pharm. 2012; 432:80-90. [PubMed: 22575754]

103. Kapoor M, Burgess DJ. Physicochemical characterization of anionic lipid-based ternary siRNA complexes. Biochim. Biophys. Acta. 2012; 1818:1603-1612. [PubMed: 22465067]

104. Kapoor M, Burgess DJ. Cellular uptake mechanisms of novel anionic siRNA lipoplexes. Pharm. Res. 2013; 30:1161-1175. [PubMed: 23239010]

105. Tseng YC, Mozumdar S, Huang L. Lipid-based systemic delivery of siRNA. Adv Drug Deliv Rev. 2009; 61:721-731. [PubMed: 19328215]

106. Ho EA, Ramsay E, Ginj M, Anantha M, Bregman I, Sy J, Woo J, Osooly-Talesh M, Yapp DT, Bally MB. Characterization of cationic liposome formulations designed to exhibit extended plasma residence times and tumor vasculature targeting properties. J. Pharm. Sci. 2010; 99:28392853. [PubMed: 20091826]

107. Senior JH, Trimble KR, Maskiewicz R. Interaction of positively-charged liposomes with blood: implications for their application in vivo. Biochim. Biophys. Acta. 1991; 1070:173-179. [PubMed: 1751523]

108. Navarro, G.; Essex, S.; Torchilin, VP. The non-viral approach for siRNA delivery in cancer treatment: a special focus on micelles and liposomes. In: Erdmann, VA.; Barciszewski, J., editors. DNA and RNA nanobiotechnologies in medicine: diagnosis and treatment of diseases. Berlin Heidelberg: Springer-Verlag; 2013. p. 255

109. Kedmi R, Ben-Arie N, Peer D. The systemic toxicity of positively charged lipid nanoparticles and the role of Toll-like receptor 4 in immune activation. Biomaterials. 2010; 31:6867-6875. [PubMed: 20541799]

110. Shi G, Guo W, Stephenson SM, Lee RJ. Efficient intracellular drug and gene delivery using folate receptor-targeted $\mathrm{pH}$-sensitive liposomes composed of cationic/anionic lipid combinations. J. Control. Release. 2002; 80:309-319. [PubMed: 11943407]

111. Lee RJ, Huang L. Folate-targeted, anionic liposome-entrapped polylysine-condensed DNA for tumor cell-specific gene transfer. J. Biol. Chem. 1996; 271:8481-7848. [PubMed: 8626549]

112. Hughes J, Yadava P, Mesaros R. Liposomal siRNA delivery. Methods Mol. Biol. 2010; 605:445459. [PubMed: 20072900]

113. Liu H, Guo S, Roll R, Li J, Diao Z, Shao N, Riley MR, Cole AM, Robinson JP, Snead NM, Shen G, Guo P. Phi29 pRNA vector for efficient escort of hammerhead ribozyme targeting survivin in multiple cancer cells. Cancer Biol. Ther. 2007; 6:697-704. [PubMed: 17426446]

114. Kesharwani P, Gajbhiye V, Jain NK. A review of nanocarriers for the delivery of small interfering RNA. Biomaterials. 2012; 33:7138-7150. [PubMed: 22796160]

115. Tenchov B, Sugimoto Y, Koynova R, Brueggemeier RW, Lee RJ. Highly efficient cationic ethylphosphatidylcholine siRNA carrier for GFP suppression in modified breast cancer cells. Anticancer Res. 2012; 32:2563-2566. [PubMed: 22753714] 
116. Piao L, Li H, Teng L, Yung BC, Sugimoto Y, Brueggemeier RW, Lee RJ. Human serum albumin-coated lipid nanoparticles for delivery of siRNA to breast cancer. Nanomedicine. 2013; 9:122-129. [PubMed: 22542825]

117. Boussif O, Lezoualc'h F, Zanta MA, Mergny MD, Scherman D, Demeneix B, Behr JP. A versatile vector for gene and oligonucleotide transfer into cells in culture and in vivo: polyethylenimine. Proc. Natl. Acad. Sci. USA. 1995; 92:7297-7301. [PubMed: 7638184]

118. Oh YK, Park TG. siRNA delivery system for cancer treatment. Adv. Drug Deli. Rev. 2009; 61:850-862.

119. Navarro G, Sawant RR, Biswas S, Essex S, Tros de Ilarduya C, Torchilin VP. P-glycoprotein silencing with siRNA delivered by DOPE-modified PEI overcomes doxorubicin resistance in breast cancer cells. Nanomedicine (Lond.). 2012; 7:65-78. [PubMed: 22191778]

120. Kong F, Liu G, Sun B, Zhou S, Zuo A, Zhao R, Liang D. Phosphorylatable short peptide conjugated low molecular weight chitosan for efficient siRNA delivery and target gene silencing. Int. J. Pharm. 2012; 422:445-453. [PubMed: 22067703]

121. Tan WB, Jiang S, Zhang Y. Quantum-dot based nanoparticles for targeted silencing of HER2/neu gene via RNA interference. Biomaterials. 2007; 28:1565-1571. [PubMed: 17161865]

122. Pangburn TO, Georgiou K, Bates FS, Kokkoli E. Targeted polymersome delivery of siRNA induces cell death of breast cancer cells dependent upon Orai3 protein expression. Langmuir. 2012; 28:12816-12830. [PubMed: 22827285]

123. Bouclier C, Moine L, Hillaireau H, Marsaud V, Connault E, Opolon P, Couvreur P, Fattal E, Renoir JM. Physicochemical characteristics and preliminary in vivo biological evaluation of nanocapsules loaded with siRNA targeting estrogen receptor alpha. Biomacromolecules. 2008; 9:2881-2890. [PubMed: 18788777]

124. Eguchi A, Dowdy SF. siRNA delivery using peptide transduction domains. Trends Pharmacol. Sci. 2009; 30:341-345. [PubMed: 19545914]

125. Sawant R, Torchilin V. Intracellular transduction using cell-penetrating peptides. Mol. Biosyst. 2010; 6:628-640. [PubMed: 20237640]

126. Law M, Jafari M, Chen P. Physicochemical characterization of siRNA-peptide complexes. Biotechnol. Prog. 2008; 24:957-963. [PubMed: 19194904]

127. Veiseh O, Kievit FM, Mok H, Ayesh J, Clark C, Fang C, Leung M, Arami H, Park JO, Zhang M. Cell transcytosing poly-arginine coated magnetic nanovector for safe and effective siRNA delivery. Biomaterials. 2011; 32:5717-5725. [PubMed: 21570721]

128. Bae KH, Lee K, Kim C, Park TG. Surface functionalized hollow manganese oxide nanoparticles for cancer targeted siRNA delivery and magnetic resonance imaging. Biomaterials. 2011; 32:176-184. [PubMed: 20934746]

129. Zhang Q, Iwakuma N, Sharma P, Moudgil BM, Wu C, McNeill J, Jiang H, Grobmyer SR. Gold nanoparticles as a contrast agent for in vivo tumor imaging with photoacoustic tomography. Nanotechnology. 2009; 20:395102. [PubMed: 19726840]

130. Wang Z, Liu G, Zheng H, Chen X. Rigid nanoparticle-based delivery of anti-cancer siRNA: challenges and opportunities. Biotechnol. Adv. 2013

131. Selim ME, Hendi AA. Gold nanoparticles induce apoptosis in MCF-7 human breast cancer cells. Asian Pacific Journal of Cancer Prevention. 2012; 13:1617-1620. [PubMed: 22799377]

132. Zhao E, Zhao Z, Wang J, Yang C, Chen C, Gao L, Feng Q, Hou W, Gao M, Zhang Q. Surface engineering of gold nanoparticles for in vitro siRNA delivery. Nanoscale. 2012; 4:5102-5109. [PubMed: 22782309]

133. Xie M, Shi H, Ma K, Shen H, Li B, Shen S, Wang X, Jin Y. Hybrid nanoparticles for drug delivery and bioimaging: Mesoporous silica nanoparticles functionalized with carboxyl groups and a near-infrared fluorescent dye. J. Colloid. Interface Sci. 2013; 395:306-314. [PubMed: 23394807]

134. Xia TA, Kovochich M, Liong M, Meng H, Kabehie S, George S, Zink JI, Nel AE. Polyethyleneimine coating enhances the cellular uptake of mesoporous silica nanoparticles and allows safe delivery of siRNA and DNA constructs. ACS Nano. 2009; 3:3273-3286. [PubMed: 19739605] 
135. Milgroom A, Intrator M, Madhavan K, Mazzaro L, Shandas R, Liu B, Park D. Mesoporous silica nanoparticles as a breast-cancer targeting ultrasound contrast agent. Colloids Surf. B Biointerfaces. 2013 pii: S0927-7765(13)00678-4.

136. Meng H, Mai WX, Zhang H, Xue M, Xia T, Lin S, Wang X, Zhao Y, Ji Z, Zink JI, Nel AE. Codelivery of an optimal drug/siRNA combination using mesoporous silica nanoparticles to overcome drug resistance in breast cancer in vitro and in vivo. ACS Nano. 2013; 7:994-1005. [PubMed: 23289892]

137. Hossain S, Stanislaus A, Chua MJ, Tada S, Tagawa Y, Chowdhury EH, Akaike T. Carbonate apatite-facilitated intracellularly delivered siRNA for efficient knockdown of functional genes. J. Control Release. 2010; 147:101-108. [PubMed: 20620182]

138. Chowdhury EH, Akaike T. High performance DNA nano-carriers of carbonate apatite: multiple factors in regulation of particle synthesis and transfection efficiency. Int. J. Nanomedicine. 2007; 2:101-106. [PubMed: 17722517]

139. Hossain S, Yamamoto H, Chowdhury EH, Wu X, Hirose H, Haque A, Doki Y, Mori M, Akaike T. Fabrication and intracellular delivery of doxorubicin/carbonate apatite nanocomposites: effect on growth retardation of established colon tumor. PLoS One. 2013; 8:e60428. [PubMed: 23613726]

140. Li YT, Chua MJ, Kunnath AP, Chowdhury EH. Reversing multidrug resistance in breast cancer cells by silencing ABC transporter genes with nanoparticle-facilitated delivery of target siRNAs. Int. J. Nanomedicine. 2012; 7:2473-2481. [PubMed: 22701315]

141. Chua MJ, Tiash S, Fatemian T, Noordin MI, Keng CS, Chowdhury EH. Carbonate apatitefacilitated intracellular delivery of c-ROS1 small interfering RNA sensitises MCF-7 breast cancer cells to cisplatin and paclitaxel. OA Cancer. 2013; 1:7.

142. Mehra NK, Mishra V, Jain NK. A review of ligand tethered surface engineered carbon nanotubes. Biomaterials. 2014; 35:1267-1283. [PubMed: 24210872]

143. Cai D, Mataraza JM, Qin ZH, Huang Z, Huang J, Chiles TC, Carnahan D, Kempa K, Ren Z. Highly efficient molecular delivery into mammalian cells using carbon nanotube spearing. Nat. Methods. 2005; 2:449-454. [PubMed: 15908924]

144. Bates K, Kostarelos K. Carbon nanotubes as vectors for gene therapy: Past achievements, present challenges and future goals. Adv. Drug Deliv. Rev. 2013; 65:2023-2033. [PubMed: 24184373]

145. Kam NWS, Liu ZA, Dai HJ. Carbon nanotubes as intracellular transporters for proteins and DNA: an investigation of the uptake mechanism and pathway. Angew. Chem. Int. Ed. Egnl. 2006; 45:577-581. 


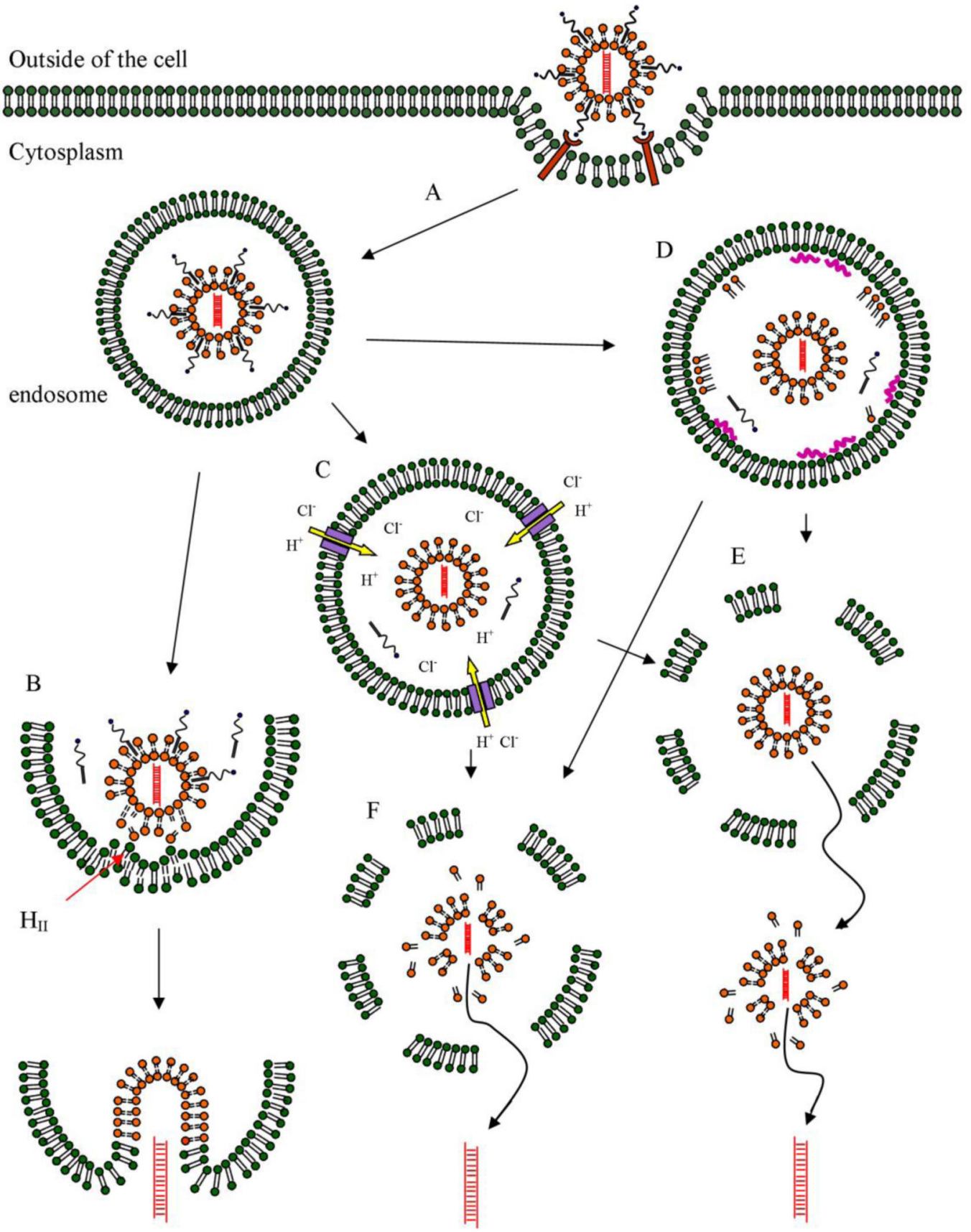

Fig. 1.

Endosome escape in liposomes mediated siRNA delivery. A. Liposomes containing siRNA (shown as orange lipid bilayer and red siRNA) with PEG and targeting ligand on the tip (shown as blue circle) are taken up by target cell via receptor mediated endocytosis. B. The cationic lipid of the liposomes forms ion pairs with the anionic endosomal lipid (PEG molecules may leave the liposomes spontaneously or under appropriate design) and can further form the inverted hexagonal phase (HII). This leads to the fusion of the liposomes with endosomal membrane and release the siRNA into cytoplasm. C. Liposomes containing 
molecules having buffer capacity in endosomal $\mathrm{pH}$ range can trigger proton sponge effect that causes the influx of $\mathrm{Cl}^{-}$and swelling of the endosome. D. Free highly positive charged molecules (shown with orange colored cationic lipid and purple colored PEI or oligoarginine) can interact with anionic endosomal membrane and destabilize it by excluding water. E. Intact liposomes may escape from the ruptured endosome and de-assemble in the cytoplasm and release siRNA if the particle is not too large for the "holes" of the ruptured endosome. F. Liposomes may also de-assemble inside the endosome and directly release siRNA out of the ruptured endosome. Reproduced with permission from [105]. 


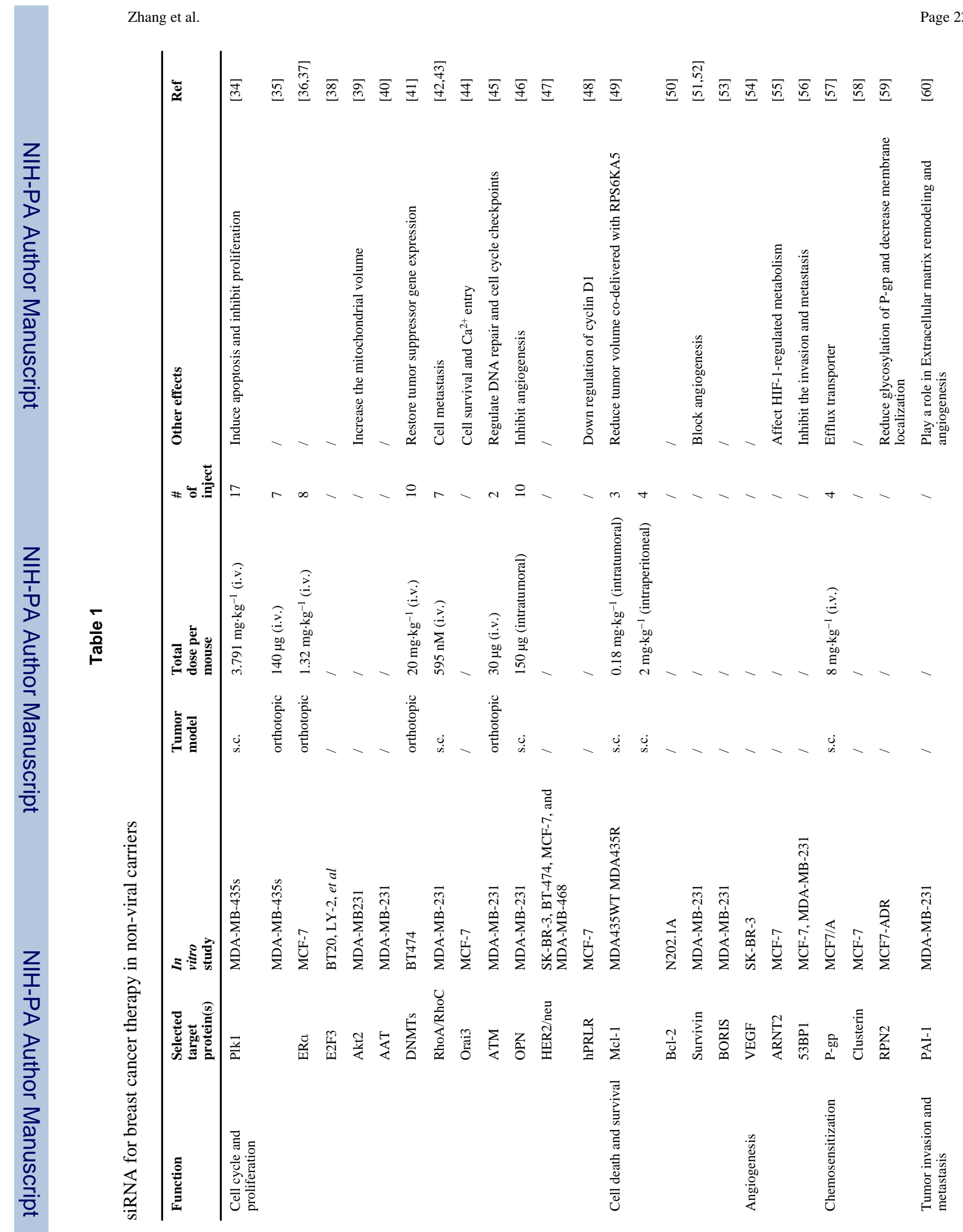

J Control Release. Author manuscript; available in PMC 2015 September 28. 


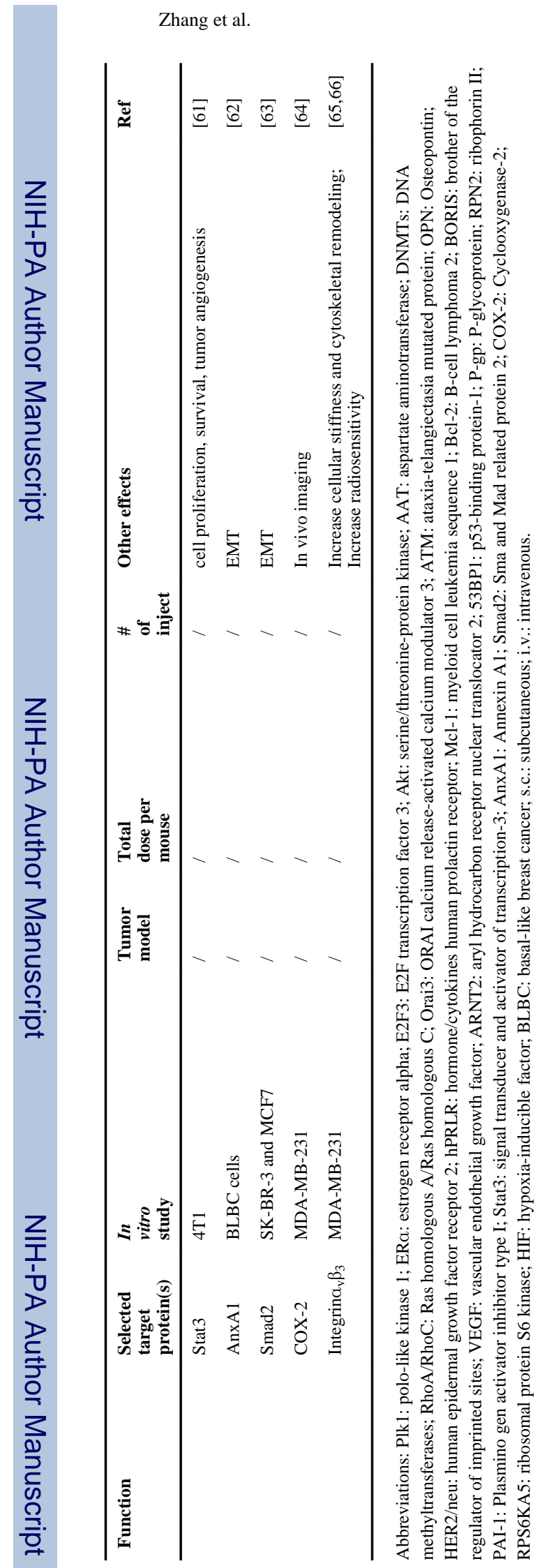

Page 23 


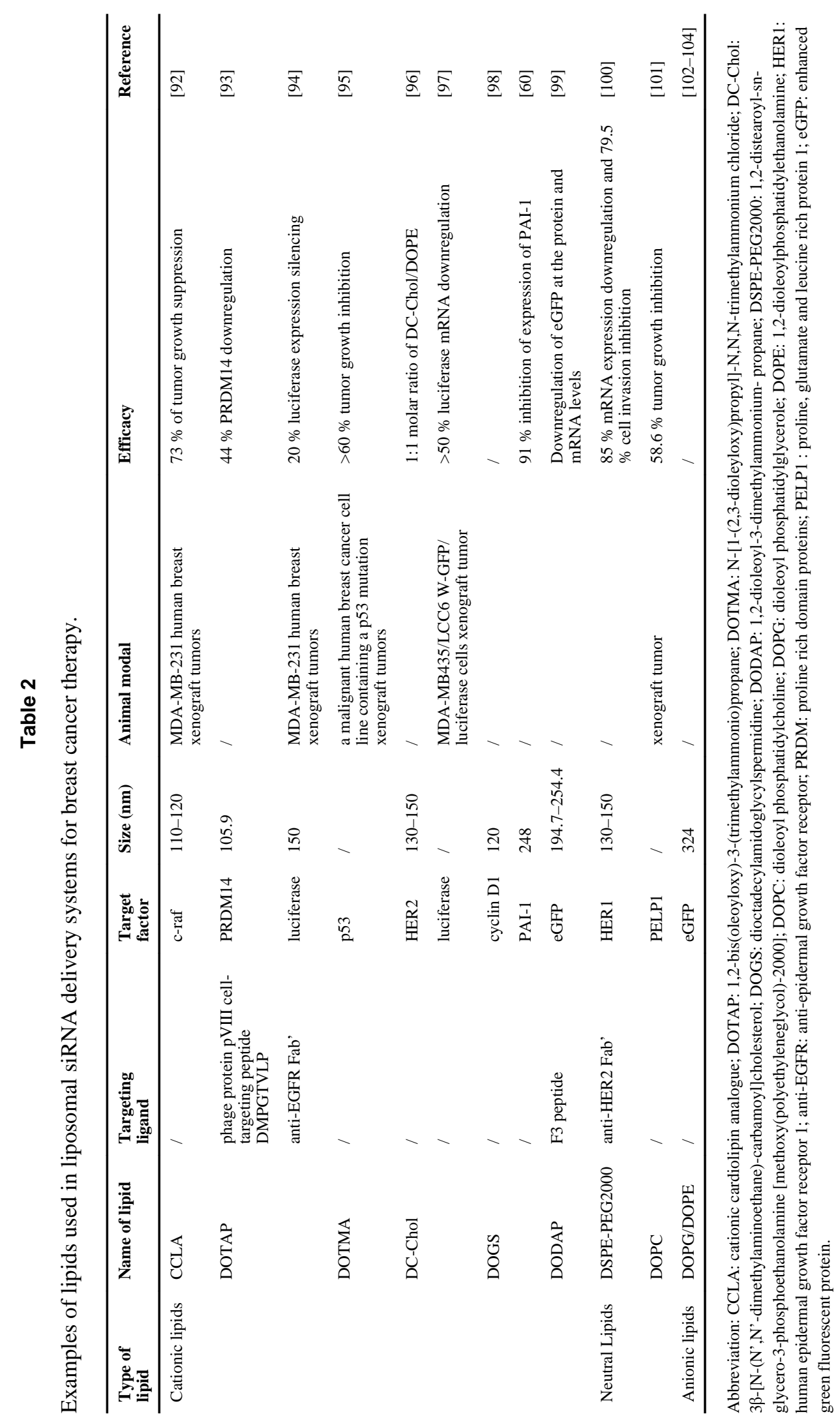

J Control Release. Author manuscript; available in PMC 2015 September 28. 